\title{
Deepest Concern*
}

\section{CHARLES FRANCIS SHERIDAN}

Dear Dick,

London, July 3d 1772.

It was with the deepest concern I received the late accounts of you, though it was somewhat softened by the assurance of your not being in the least danger. You cannot conceive the uneasiness it occasioned to my father. Both he and I were resolved to believe the best, and to suppose you safe, but then we neither of us could approve of the cause in which you suffer. All your friends here condemned you. You risked every thing, where you had nothing to gain, to give your antagonist the thing he wished, a chance for recovering his reputation. Your courage was past dispute: - he wanted to get rid of the contemptible opinion he was held in, and you were good-natured enough to let him do it at your expense. It is not now a time to scold, but all your friends were of opinion you could, with the greatest propriety, have refused to meet him. For my part, I shall suspend my judgement till better informed, only I cannot forgive your preferring swords.

I am exceedingly unhappy at the situation I leave you in with respect to money matters, the more so as it is totally out of my power to be of any use to you. Ewart ${ }^{1}$ was greatly vexed at the manner of your drawing for the last 20l. - I own, I think with some reason.

As to old Ewart, ${ }^{2}$ what you were talking about is absolutely impossible; he is already surprised at Mr Linley's long delay, and, indeed, I think the latter much to blame in this respect. I did intend to give you some account of myself since my arrival here, ${ }^{3}$ but you cannot conceive how I have been hurried, - even much pressed for time at this present writing. I must therefore conclude, with wishing you speedily restored to heath, and that if I could make your purse as whole as that will shortly be, I hope, it would make me exceedingly happy.

I am, dear Dick, yours sincerely,

G. F. Sheridan.

* From Moore, Memoirs of Sheridan, 1, 70-1. Editor's title. 